\title{
BIOCHEMICAL EFFECTS OF THE ENTOMOPATHOGENIC FUNGUS, BEAUVERIA BASSIANA ON THE RED PALM WEEVIL, RHYNCHOPHORUS FERRUGINEUS
}

\author{
RAGHEB, DIDAIR A. ${ }^{2}$, M. A. ALI ${ }^{1}$, H. K. BEKHIET ${ }^{1}$ and \\ A. A. EL-FESHAWAY2 \\ 1. Plant Prot. Inst., Agric. Res. Cent., Dokki, Giza, Egypt \\ 2. Plant Prot. Dept., Fac. Agric., Zagazig Univ., Egypt \\ * Corresponding author: Tel. : +201065053461 \\ E-mail address: abdelsalam_eg@yahoo.com
}

(Manuscript received 28 August 2017)

\begin{abstract}
$\mathrm{F}$ ourth instar larval was chosen to evaluate the biochemical activity (proteases, Chitinases and $a-\& \beta$-esterases) of the red palm weevil treated by Beauveria bassiana under laboratory conditions. Biochemical analysis of the haemolymph indicated that the fungus, B. bassiana-9894 increased proteases, Chitinases and a- \& $\beta$-esterases enzymes level compared with control. The level of total protein was decreased, meanwhile, the total lipids were increased compared with control.

Key words: Rhynchophorus ferrugineus, entomopathogens, Beauveria bassiana, enzymes.
\end{abstract}

\section{INTRODUCTION}

The red palm weevil, Rhynchophorus ferrugineus (Olivier) belongs to the family of Curculionidae (Coleoptera). $R$. ferrugineus is a major economic pest of coconut palm, date palm, oil palm and sago palm. It also attacks a wide range of ornamental palms. It has been known first in south east Asia until it appeared in United Arab Emirates in 1985, Kingdom of Saudi Arabic in 1987 and Egypt in 1992 (Saleh, 1992).

Entomopathogenic fungi differ from other insect pathogens in their ability to invade a host by direct penetration of the cuticle, which is essentially composed of proteins and chitin associated with lipids and phenolic compounds.

One of the advantages of entomopathogenic fungi is that the host insect need not ingest those. Entomopathogenic fungi, such as Beauveria bassiana, infect the host insect by penetrating the insect cuticle. The fungal conidium attaches to the cuticle by nonspecific hydrophobic mechanism and subsequently germinates. The insect cuticle consist primary of a chitin matrix embedded with proteins. Entomopathogenic fungi produce extracellular proteases and chitinases that degrade these proteinaaceous and chitinous components, allowing hyphal penetration through the cuticle and access to the nutrient-rich insect hemolymph (Charnley and Legar 
1991). Proteases, particularly the subtilisin -like protease called $\operatorname{Pr} 1$, and the chitinases Bbchit1 (Fang et al., 2005) are important virulence factors for B. bassiana. Chitinases are widely distributed and are found in viruses, bacteria, fungi, plants and animals. Some of these chitinases contain a chitin-binding domain linked to the catalytic site via an intermediate region (Beintema, 1994). Chitin is an important component of insect cuticle, which is the primary barrier against pathogens. Chitinases are required by the fungus for both penetration through the cuticle barrier and when emerging from the host (Fang et al. 2005). Over expression of Bbchit 1 was able to increase the ability of $B$. bassiana to digest insect cuticle, resulting increased virulence against insect (Fang et al., 2005). Entomopathogenic fungi, such as $B$. bassiana, penetrate the insect cuticle utilizing a plethora of hydrolytic enzymes, including chitinases, which are important virulence factors ( Yanhura et al., 2007).

Insect cuticle is a composite structural material with mechanical properties that are optimal for their biological functions. The cuticle consists of a thin outer epicuticle containing lipids and proteins and a thick procuticle consisting mainly of chitin and proteins (Andersen et al., 1995). Entomopathogenic fungi enter their hosts through direct penetration of the cuticle, which is a barrier against most microbes. Consequently, fungal pathogens have a potential as a biological means of controlling sap-sucking insects that have not been easily controlled with chemical pesticides. During the fungal penetration through the host cuticle, hydrolytic enzymes such as proteases, chitinases, and lipases are produced and secreted and are important for the initiation of the infection process (Yang and Yeh, 2005). Investigations on insect proteins and lipids found in both haemolymph and body fat are of particular interest because they provide us with an adequate background to investigate the synthetic activities associated with the different processes in developing organisms.

\section{MATERIALS AND METHODS}

\section{Red palm weevil, Rhynchophorus ferrugineus (Olivier).}

The red palm weevil, $R$. ferrugineus were reared on the stems of sugarcane as described by KaaKeh et al., (2001) under laboratory conditions at $28 \pm 1^{\circ} \mathrm{C}$ and 60 $70 \%$ R.H. Adult weevils were collected from infested date palm trees at plantation locations at El-Kassasin area, Ismailia Governorate, Egypt.

\section{Beauveria bassiana.}

The strain of $B$. bassiana-9894 used in this study was isolated from infected cadaver adults of $R$. ferrugineus collected from El-Kassasin area. Isolated fungus was purified and identified in Assuit University Mycological Center (AUMC). 


\section{Culture of entomopathogenic fungus, $B$. bassiana-9894:}

The conidia fungus were cultured on agar Petri dishes of Dox medium (Thom and Raper., 1945). The medium consists of Sucrose $20 \mathrm{~g} / \mathrm{L}$, $\mathrm{KHPO}_{4} 1 \mathrm{~g} / \mathrm{L}, \mathrm{KNO}_{3} 2 \mathrm{~g} / \mathrm{L}, \mathrm{KCl} 0.5 \mathrm{~g} / \mathrm{L}$, Yeast extract 2g/L, $\mathrm{MgSO}_{4} .7 \mathrm{H}_{2} \mathrm{O} 0.5 \mathrm{~g} / \mathrm{L}$, $\mathrm{FeSO}_{4} .7 \mathrm{H}_{2} \mathrm{O} 0.002 \mathrm{~g} / \mathrm{L}$ and agar $20 \mathrm{~g} / \mathrm{L}$ and incubated at $25 \pm 2{ }^{\circ} \mathrm{C}$ and $60-70 \%$ R.H for two weeks. At the end of incubation period the conidia were harvested from the surface of the culture directly by scraping with sterile solution of $0.02 \%$ Tween- 80 . The conidia were separated by filtration through sterilized glass-wool. For experimental work, conidia of $B$. bassiana-9894 were suspended in $50 \mathrm{ml}$ sterile distilled water with $0.02 \%$ Tween- 80 and vortexes for 1 minute to break spore chains into individual spores and assure uniform mixing. Spores suspended in sterilized water were counted using haemocytometer counts technique (Goettel and Inglis 1997).

\section{Effect of B. bassiana-9894 on some biochemical parameters in red palm weevil $R$. ferrugineus.}

Fourth instar larval was chosen to evaluate the biochemical activity of red palm weevil (protease, chitinase, a-esterase and $\beta$-esterase) under laboratory conditions. Four replicates of $4^{\text {th }}$ instar larvae were directly immersed for $60 \mathrm{sec}$. in a conidia aqueous suspension of $\mathrm{LC}_{50}$ value $\left(1.1 \times 10^{6} \mathrm{spores} / \mathrm{ml}\right)$ and transferred onto plastic boxes ( 5 larvae per box) containing filter paper for $24 \mathrm{~h}$ then transferred onto plastic boxes containing $50 \mathrm{~g}$ of moist sugar cane sawdust and succulent pieces of sugarcane stems and incubated at $28^{\circ} \mathrm{C}$. The live larvae were collected after $2,3,5$ and 7 days post-treatment to biochemical assay.

\subsection{Preparation of larval homogenates.}

The collected larvae $(1 \mathrm{gm})$ were homogenized in distilled water $(1: 4 \mathrm{w} / \mathrm{v})$ at 500 rpm using a Teflon homogenizer- (MECHIANIKA PRECYZYJNA Warszawa type MPN-309-Poland)-surrounded with a jacket of crushed ice for 3minutes. Homogenates were centrifuged at $6000 \mathrm{rpm}$ for $10 \mathrm{~min}$ at $5^{\circ} \mathrm{C}$ using (BECKMAN GS-6R Centrifuge). After centrifugation, the supernatant was divided into small aliquots $(0.5 \mathrm{ml})$ and stored at $-20^{\circ} \mathrm{C}$ until analysis. Three replicates were carried out for each biochemical determination.

\subsubsection{Determination of chitinase activity.}

Chitinase was assayed using 3,5-dinitrosalicylic acid reagent to determine the free aldehydic groups of hexosamine liberated on chitin digestion according to the method described by Ishaaya and Casida (1974). 


\section{Preparation of 3, 5-dinitrosalicylic acid reagent (DNSA)}

The dinitosalicylic acid reagent was prepared by dissolving one gram of 3, 5dinitrosalicylic acid in $20 \mathrm{ml}$ of $2 \mathrm{~N} \mathrm{NaOH}$ solution and $50 \mathrm{ml}$ of distilled water with the aid of a magnetic stirrer. Potassium sodium tartarate (30 gm) was added, and magnetic stirring was continued until a clear solution was obtained. Distilled water was then added to bring the final volume to $100 \mathrm{ml}$.

\section{Assay of chitinase activity}

The reaction mixture consisted of $0.12 \mathrm{ml}(0.2 \mathrm{M})$ phosphate buffer ( $\mathrm{pH} 6.6)$; $0.3 \mathrm{ml}$ of $0.5 \%$ colloidal chitin; $0.18 \mathrm{ml}$ sample homogenate. After 60 min incubation at $37^{\circ} \mathrm{C}$, enzyme activity was terminated by adding $1.2 \mathrm{ml} \mathrm{3,5-dinitrosalycilic} \mathrm{acid}$ agent (DNSA). The reaction mixture was heated for $5 \mathrm{~min}$ at $100^{\circ} \mathrm{C}$ then cooled in an ice-bath, and diluted with $1.2 \mathrm{ml}$ distilled water. Undigested chitin was sedimented by centrifugation for $15 \mathrm{~min}$ at $6000 \mathrm{rpm}$ and the absorbance of the supernatant was determined spectrophotometrically at $500 \mathrm{~nm}$. Direct reaction of Nacetylglucosamine (NAGA) with DNSA reagent, under conditions similar to those of the enzyme reaction, gives a linear plot of absorbance value versus amount of NAGA, $1 \mu \mathrm{g}$ of NAGA giving an absorbance value of 0.78 . Chitinase activity is expressed as $\mu \mathrm{g} \mathrm{N}$ acetylglucosamine released/gm body weight/min.

\subsubsection{Determination of protease activity.}

The protease activity was determined by the casein digestion method described by Ishaaya et al. (1971). The reaction mixture consisted of $0.2 \mathrm{ml}(0.2 \mathrm{M})$ glycine buffer $(\mathrm{pH} 10,0.4 \mathrm{ml}$ of $1.5 \%$ casein solution, and $0.2 \mathrm{ml}$ homogenate sample. Enzymatic activity was terminated after $60 \mathrm{~min}$ incubation at $37^{\circ} \mathrm{C}$ by adding $1.2 \mathrm{ml}$ of $5 \%$ trichloroacetic acid solution. The reaction mixture was centrifuged at $6000 \mathrm{rpm}$ for $15 \mathrm{~min}$ and the supernatant was taken for enzymatic activity evaluation. The proteolytic activity was determined at $280 \mathrm{~nm}$ as O.D. (Optical Density) unit for samples $\times 10^{3}$. Protease activity was expressed as $\mu \mathrm{g}$ tyrosine/gm body weight.

\subsubsection{Determination of non- specific esterase Activities.}

Alpha and beta esterases ( $a-\beta)$ were determined according to the method of Van Asperen (1962) using a-naphthyl acetate and $\beta$-naphthyl acetate as substrates, respectively. This method depends on the Naphthol produced as a result of substrate hydrolysis can be measured by the addition of diazoblue sodium lauryl sulphate solution which produce a strong blue color in case of a-naphthol or strong red color in the case of $\beta$ - naphthol. The colour was measured spectrophotometrically.

The reaction mixture consisted of $5 \mathrm{ml}$ substrate solution $\left(3 \times 10^{-4} \mathrm{M}\right.$ a- or $\beta$ naphthylacetate), $1 \%$ acetone and $0.04 \mathrm{M}$ phosphate buffer $\mathrm{pH} 7$ and $20 \mu \mathrm{l}$ of larval homogenate. The mixture was incubated for exactly $15 \mathrm{~min}$ at $27 \mathrm{C}^{0}$. Then I $\mathrm{ml}$ of 
diazoblue color reagent (prepared by mixing 2 parts of $1 \%$ diazoblue $\beta$ and 5 part of $5 \%$ sodium lauryl sulphate) was added. The developed color was read at 600 and $555 \mathrm{~nm}$ for $\mathrm{a}$-and $\beta$-naphthol, respectively. The activity was expressed as $\mu \mathrm{g} a-$ or $\beta$ naphthol released/ $\mathrm{min} / \mathrm{gm}$ body weight.

\section{Preparation of standard Curves of a-and $\beta$-naphthol.}

Stock solution were prepared by dissolving $20 \mathrm{mg}$ a- or $\beta$-naphthol in $100 \mathrm{ml}$ of $0.04 \mathrm{~m}$ phosphate buffer $(\mathrm{pH} \mathrm{7})$ ten milliliter of stock solution were diluted up to $100 \mathrm{ml}$ by the phosphate buffer Aliquots containing of $2.5,5,10,20$ and $40 \mu \mathrm{g}$ of anaphthol or $2.5,5,7.5,10$ and $20 \mu \mathrm{g} \beta$ - naphthol were pipetted into test tubes and completed to $5 \mathrm{ml}$ by phosphate buffer, one milliiter of diazoblue reagent was added and the developed color was measured as mentioned before. The standard curves of both $\alpha-E$ and $\beta-E$ were blotted by O. D (Optical Density) against concentration.

\subsubsection{Determination of total proteins content.}

Total proteins were determined by the method of Bradford (1976)

using standard of Bovine serum albumin.

preparation of protein reagent

Coomassie Brilliant Blue G-250 (100mg) was dissolved in $50 \mathrm{ml}$ of $95 \%$ ethanol. To this solution, $100 \mathrm{ml} 85 \%$ (w/v) phosphoric acid were added. The resulting solution was diluted to a final volume of 1 liter.

\section{preparation of standard curve of protein}

For preparation of standard curve serial concentrations of Bovine serum albumin solutions containing 10 to $100 \mu \mathrm{g}$ of protein were pipetted into test tubes and the volume was adjusted to $0.1 \mathrm{ml}$ with phosphate buffer $(\mathrm{pH} 6.6)$. Five $\mathrm{ml}$ of protein reagent were added and the resulting color was measured spectrophotometrically at $595 \mathrm{~nm}$ after 2 minutes. The optical densities against concentrations, thus a curve can be constructed.

\section{Protein assay.}

$50 \mu$ l of larval homogenate were pipetted into a test tube containing $50 \mu l$ phosphate buffer ( $\mathrm{pH} \mathrm{6.6)}$, then $5 \mathrm{ml}$ of protein reagent were added to the test tube and the contents were vortexed. The absorbance at $595 \mathrm{~nm}$ was measured after 2 min against blank prepared from $0.1 \mathrm{ml}$ of phosphate buffer $(\mathrm{pH} \mathrm{6.6)}$ and $5 \mathrm{ml}$ of protein reagent. The content of protein was obtained from the standard curve and expressed as mg protein / gram.

\subsubsection{Determination of total lipid content.}

Total lipid content in $R$. ferrugineus larval homogenate was estimated according to Knight et al. (1972) using phosphovanillin reagent. 
Pure vanillin $(0.6 \mathrm{gm})$ was dissolved in $10 \mathrm{ml}$ absolute ethanol and complete to $100 \mathrm{ml}$ distilled water. Concentrated phosphoric acid (400 ml) was added, and the solution was stored in dark glass bottle at room temperature.

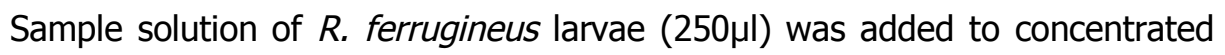
sulfuric acid $(5 \mathrm{ml})$ in a test tube and heated in a boiling water bath for $10 \mathrm{~min}$. after cooling to room temperature, $500 \mu \mathrm{l}$ of digested sample was added to phosphovanillin reagent $(6.0 \mathrm{ml})$. After $45 \mathrm{~min}$ incubation in dark, the developed color was measured at $525 \mathrm{~nm}$ against reagent blank prepared from $500 \mu \mathrm{l}$ distilled water and $6.0 \mathrm{ml}$ phosphovanillin reagent. The result is expressed as $\mu \mathrm{g}$ lipid/gram body weight.

For standard curve, serial concentrations of oleic acid and palmitic acid mixture (7:3) from 1 to $5 \mathrm{mg} / \mathrm{ml}$ were prepared in absolute ethanol were used and treated in the same manner as the unknown. The standard curve was blotted by O.D. (Optical Density) against concentration.

\section{Analysis of results.}

Experimental data were analyzed using one way analysis of variance (ANOVA) using SPSS (statistical package for social sciences, ver. 20), and the significance among the samples was compared at $\mathrm{P} \leq 0.05$. Results were represented as mean $\pm \mathrm{SE}$ $(n=4)$.

\section{RESULTS AND DISCUSSION}

\section{Effect of B. bassiana-9894 on some biochemical parameters in red palm weevil.}

Fourth instar larval was chosen to evaluate the biochemical activity of red palm weevil (Proteases, Chitinases and a- $\& \beta$-esterases) under laboratory conditions. $B$. bassiana-9894 isolate was found to be the most effective isolate against the different stages of the red palm weevil, $R$. ferrugineus (Ali et al., 2015).

\section{Effect on proteases, chitinases and a \& $\beta$-esterase.}

The changes in activity of haemolymph proteases, chitinases and a-\& $\beta$ esterase in $4^{\text {th }}$ instar larvae of red palm weevil, $R$. ferrugineus treated by $\mathrm{LC}_{50}$ (i.e., $1.1 \times 10^{6}$ spores $/ \mathrm{ml}$ ) entomopathogenic fungus after $2,3,5$ and 7 days were illustrated in Table (1).

Data in Table (1) showed that a significant increase in proteases, chitinases and a $\& \beta$-esterases in haemolymph of $4^{\text {th }}$ instar larvae of red palm weevil, $R$. ferrugineus treated by entomopathogenic fungus compared with the control larvae.

Results indicated that a significant increase $(p<0.05)$ in the activity of protease after 2, 3, 5 and 7 days as compared with control. On the other hand, the activity of protease was increased significant $(p<0.05)$ after 3,5 and 7 days in 
comparison with 2 days. While after 3 and 5 days the activity of haemolymph protease in experimental larvae had no significant increased. Meanwhile, after 7days the activity of protease in haemolymph of fourth instar larvae had increased significantly compared with control and remained at a level higher than that of 2, 3 and 5 days.

Table 1 . Enzyme activities of $4^{\text {th }}$ instar larvae of red palm weevil as affected by $B$. bassiana-9894 treatment.

\begin{tabular}{|c|c|c|c|c|}
\hline $\begin{array}{l}\text { Days after } \\
\text { treatment }\end{array}$ & $\begin{array}{c}\text { Protease ( } \mu g \\
\text { tyrosine/gm body } \\
\text { weight/min) }\end{array}$ & $\begin{array}{c}\text { Chitinase ( } \mu \mathrm{g} \mathrm{N} \text { - } \\
\text { acetylglucosamine /gm body } \\
\text { weight/min) }\end{array}$ & $\begin{array}{l}\text { a-esterase ( } \mu \mathrm{g} \text { a- } \\
\text { naphthol /g body } \\
\text { weight/min) }\end{array}$ & $\begin{array}{c}\beta \text {-esterase }((\mu \mathrm{g} \beta \text { - } \\
\text { naphthol /g body } \\
\text { weight/min) }\end{array}$ \\
\hline 2days & $44.63^{a_{c}, c, d, e} \pm 1.87$ & $40.17^{\mathrm{d}, e} \pm 2.98$ & $388.81^{a, c, d, d, e} \pm 16.48$ & $243.23^{e} \pm 16.93$ \\
\hline 3days & $51.99^{a, b, e} \pm 1.49$ & $42.01^{\mathrm{d}, \mathrm{e}} \pm 2.01$ & $450.87^{a, b, d, d, e} \pm 21.70$ & $267.16^{\mathrm{a}, \mathrm{e}} \pm 12.56$ \\
\hline 5days & $54.77^{a, b, e} \pm 1.92$ & $48.89^{a, b, c, e} \pm 0.75$ & $466.21^{a, b, e} \pm 21.48$ & $293.47^{\mathrm{a}, \mathrm{e}} \pm 22.69$ \\
\hline 7days & $64.63^{a, b, c, d} \pm 2.44$ & $70.88^{a, b, c, d} \pm 3.15$ & $632.56^{a, b, c, d} \pm 16.32$ & $586.89^{a, b, c, d} \pm 38.98$ \\
\hline control & $38.69 \pm 1.01$ & $36.26 \pm 1.52$ & $338.54 \pm 6.72$ & $207.16 \pm 18.58$ \\
\hline
\end{tabular}

All data are expressed as means \pm SE.a. Significant different versus control at $p<0.05, b$. Significant different versus after 2 days at $p<0.05$, c. Significant different versus after 3days at $p<0.05$, d. Significant different versus after 5 days at $p<0.05$, e. Significant different versus after 7days at $p<0.05$

The activity of chitinase was increased significantly $(p<0.05)$ after 5 and 7 days compared with control (Table 1 ). Meanwhile, after 5 and 7 days the activity of haemolymph chitinase in $4^{\text {th }}$ instar larvae had increased significantly and remained at a level higher than that of the control. But after 2 and 3 days no significantly increase observed in activity of haemolymph chitinase concentration compared with control.

Results in table (1) shown a significantly increased in a-esterase activity in haemolymph of $4^{\text {th }}$ instar larvae of red palm weevil treated with B. bassiana-9894 after 2, 3, 5 and 7 days compared with control. While $\beta$-esterase obtained a significantly increased in haemolymph after 3,5 and 7 days compared with control. From aforementioned results, it is obvious that the fungus, B. bassiana-9894 caused a significant increase after 2, 3, 5 and 7 days in activity of protease, chitinase, aesterase and $\beta$-esterase.

\section{Effect on total protein and total lipids.}

Data in table (2) showed that the total protein content in haemolymph of $4^{\text {th }}$ instar larvae decreased from 3, 5 and 7 days after treatment. The results showed a significant decrease $(p<0.05)$ in the total protein concentration after 5 and 7 days compared with control. The changes in the total lipids concentration of $4^{\text {th }}$ instar larvae of red palm weevil treated by entomopathogenic fungus as demonstrated in 
table (2). Results obtained revealed that a significant increased in total lipids concentration after 3, 5 and 7 days compared with untreated larvae. But, after 5 days of treatment no significant increased was obtained compared with 2 and 3 days. Meanwhile, results shown a significantly increased in total lipids concentration in haemolymph of $4^{\text {th }}$ instar larvae of red palm weevil after 7 days compared with control and 2,3 and 5 days.

Table 2. Total protein and total lipids of $4^{\text {th }}$ instar larvae of red palm weevil as affected by $B$. bassiana treatment.

\begin{tabular}{|c|c|c|}
\hline Treatment & Total protein $(\mathrm{mg} / \mathrm{ml})$ & Total lipids $(\mu \mathrm{g} / \mathrm{g}$ body weight) \\
\hline 2days & $1.28^{\mathrm{a}, \mathrm{c}, \mathrm{d}} \pm 0.09$ & $130.99^{\mathrm{e}} \pm 9.91$ \\
\hline 3days & $1.04^{\mathrm{b}, \mathrm{d}} \pm 0.06$ & $240.48^{\mathrm{a}, \mathrm{e}} \pm 7.11$ \\
\hline 5days & $0.80^{\mathrm{a}, \mathrm{b}} \pm 0.06$ & $268.76^{\mathrm{a}, \mathrm{b}, \mathrm{c}, \mathrm{d}, \mathrm{d}} \pm 11.87$ \\
\hline 7days & $0.51^{\mathrm{a}, \mathrm{b}, \mathrm{c}} \pm 0.06$ & $73.78 \pm 5.14$ \\
\hline Control & $1.14^{\mathrm{a}} \pm 0.09$ & \\
\hline
\end{tabular}

All data are expressed as means \pm SE.a. Significant different versus control at $p<0.05, b$. Significant different versus after 2 days at $p<0.05$, c. Significant different versus after 3days at $p<0.05$, d. Significant different versus after 5 days at $p<0.05$, e. Significant different versus after 7 days at $p<0.05$

At the present study, Beauveria bassiana-9894 severely deplete the protein concentration. The entomopathogenic fungi (B. bassiana and $M$. anisopliae) siginficanly decreased the immune enzyme activity and protein concentration (Gabarty et al., 2013). Insect infected with the fungi was declined its total protein concentration, it was dramatically declined in desert locust treated by Metarhizium anisopliae (Elbanna et al., 2012). reduction in the total protein content of the adult haemolymph of Schistocerca gregaria reported during the course of infection with the M. anisopliae (Gillespie et al., 2000). The reduction in total protein and loss of soluble protein from the host haemolymph during parasitism may be due to proteolytic enzymes which were secreted into the haemoceol of the insect and hydrolyze the host protein (Gillespie et al., 2000). Decreasing the total protein content may lead to the death of treated insects and this may be one of the reasons of insect mortality. The reduction or the lack of protein leads to retardation of many physiological processes in insects, adult insect requires protein to promote ovulation and egg development supports this conclusion (House, 1963). 


\section{CONCLUSION}

The results indicated a significant ( $P \leq 0.05)$ increase in the protease, chitinase and a \& $\beta$-esterases in $4^{\text {th }}$ instar larvae of $R$. ferrugineus, this increase was greatly remarkable in 7 days after treatment. The results indicated a significant ( $P \leq$ 0.05 ) decrease in total protein content of $4^{\text {th }}$ instar larvae of $R$. ferrugineus resulted from treated larvae with $\mathrm{LC}_{50}$ of entomopathogenic fungus, B. bassiana-9894.

On the other hand, the results showed a significant $(P \leq 0.05)$ increase on total lipids in the $4^{\text {th }}$ instar larvae which treated with $\mathrm{LC}_{50}$ of $B$. bassiana-9894.

\section{REFRENCES}

1. Ali, M. A.; El-Feshaway, Didair A. Ragheb, A.A. and H.K. Bekhiet. 2015. Efficiency and histological effect of Beauveria bassiana (Bals.) Vuill on the red palm weevil, Rhynchophorus ferrugineus (Olivier) (Coleoptera : Curculionidae). Zagazig J. Agric. Res., Vol. 42 No. (2): 345-356.

2. Andersen, S.O., P. Hojrup and P. Roepstorff. 1995. Insect cuticular proteins. Insect Biochem. mol. Biol., 25: 153-176.

3. Beintema, J.J. 1994. structural features of plant chitinases and chitin-binding proteins. FEBS Lett. 350: 159-163.

4. Bradford, M. M. 1976. A rapid and sensitive method for the quantitation of microgram quantities of protein utilizing the principle of protein-dye binding. Anal. Bioche. 72: 248-254.

5. Charnley A.K., and R.J. St. Leger. 1991. The role of cuticle degrading enzymes in fungal athogensis in insects. In: Cole G..T., and Hoch H.C.(eds.), The fungal spore and disease initiation in palnt and animals, Plenum, New York, pp. 267-286.

6. Clarkson. J. M., and A. K. Charnley. 1996. New insights into the mechanisms of fungal pathogenesis in insects. Trends Microbiol. 4: 197-203.

7. Elbanna, S. M.; M. N. Elhadidy; M. Fayez; M. Semida and T. Abdel-Rasool 2012. Physiological and biochemical effect of entomopathogenic fungus Metarhizium anisopliae the $5^{\text {th }}$ instar of Schistcereca gregaria (Orthoptera: Acrididae). J. Research in Environmental Sci. and Toxicol., 1(1):7-18.

8. Fang, W., B. Leng, Y. Xiao, K. Jin, J. Ma, Y. Fan, X. Yang, Y. Zhang, and Y. Pei. 2005. cloning of Beauveria bassiana chitinases gene Bbchit 1 and its application to improve fungal strain virulence. Appl. Environ. Microbiol. 71: 363-370.

9. Gabarty, A.; S. M. El-Sonbaty and A. A. Ibrahim. 2013. Synergistic effect of gamma radiation and entomopathogenic fungi Beauveria bassiana and Metarhizium anisopliae on the humoral immune enzyme response in cotton leaf worm, 
Spodoptera littolaris (Boisd). Egypt. Acad. J. Biolog. Sci., 6(3):1-10.

10. Gillespie, J. P.; C. Burnett and A. K. Charnley. 2000. The immune response of the desert locust, Schistcereca gregaria during mycosis of the entomopathogenic fungus, Metarhizium anisopliae var. acridum. J. Physiol. 46: 429-437.

11. Goettel, M. S. and G. D. Inglis. 1997. Fungi: Hyphomyctes. In: Lacey, L.A. (ed.) Manual of techniques in Insect Pathology. Academic Press, London, 213-249.

12. House, H. L. 1963. Nutrition in physiology of insects (Rockstein, ed) $2^{\text {nd }}$ ed. Vol. 5 : 791-821. Academic press. N. Y. and London.

13. Ishaaya, I. and J. E. Casida. 1974. Dietary TH 6040 alters composition and enzyme activity of housefly larval cuticle. Pestic. Biochem. Physiol., 4: 484-490.

14. Ishaaya, I., I. Moorie and D. Joseph. 1971. Protease and amylase activity in the larvae of the Egyptian cotton worm, Spodoptera littoralis (L). J. Insects physiol., 17: 945-95.

15. Kaakeh, W.; M. Aboui-Anour and A. A.Khamis. 2001. Mass rearing of the red palm weevil, Rhynchophorus ferrugineus (Oliv.) on sugarcane and artificial diets for laboratory studies. Pp.344-357. proceedings of the Second International Conference on Date Palm (refereed), Al-Ain, UAE.

16. Knight, J. A; S. Anderson and J. M. Rawle. 1972. Chemical basis of the sulfophospho-vanillin reaction for estimating total serum lipids. Clin. Chem., 18:199- 202.

17. Saleh, M. R. A. 1992. Red palm weevil Olivier is first record in Egypt and indeed in African continent List No. 10634 Africa Collection No.22563. International Institute of Entomology. 56 Queen's Gate, London, Uk.

18. Thom, C. and K. B Raper. 1945. Amanual of Aspergillus Willamas and Wilkins Co. Batimore, Mol.

19. Van Asperen, K. 1962. A study of housefly esterases by means of a sensitive colorimetric method. J. In sect Physiol., 8: 401-416.

20. Yang, A.H. and Yeh, K.W., 2005. Molecular cloning, recombinant gene expression, and antifungal activity of cystatin from taro (Colocasia esculenta cv. Kaosiung no.1). Planta, 221: 493-501. 


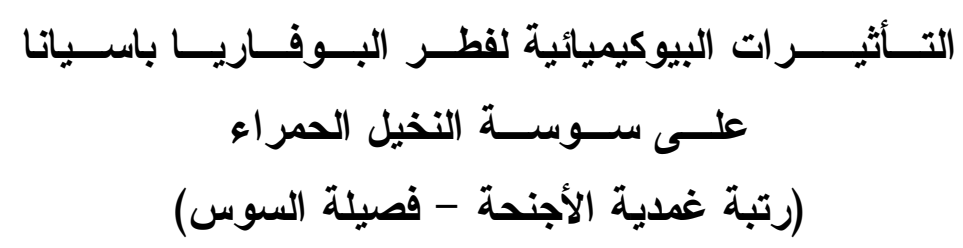

ديدير أحمد راغب' - محمد عبد السلام على' - حسن قاسم بخيت' - عادل عبد الحميد الفيشاوى'

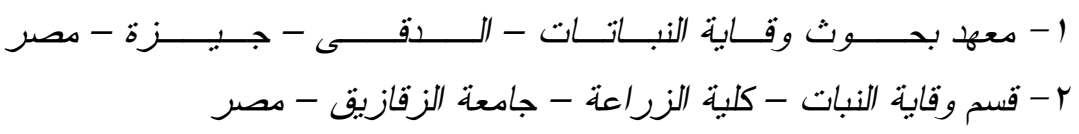

تم أختيار العمر اليرقى الرابع لسوسة النخيل الحمراء المعامل بالفطر بوفاريا باسيانا لتقييم النشاط البيوكيميائى (البروتييز و الثيتينيز والأستيرزس) تحت الظروف ليعت المعملية. وأثنارت التحاليل

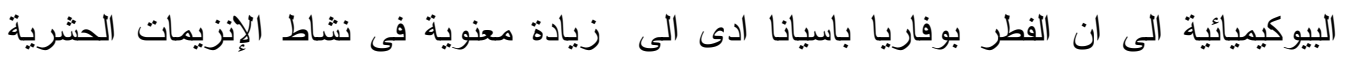

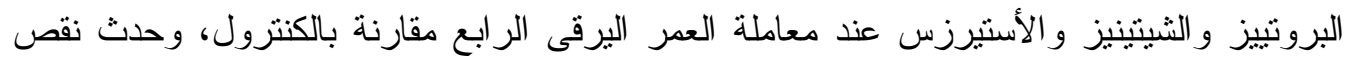

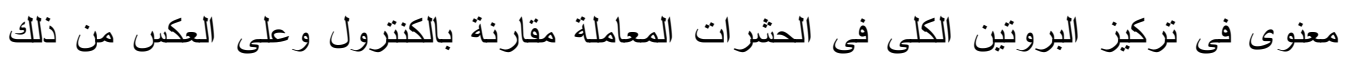
كانت هنالك زيادة معنوية فى تركيز الليبيدات الكلية مقارنة بالكنترول. 
